\title{
Avrupa Birliği'nin Enerji Güvenliği: Enerji İthalatı Bağımlılığı ve Ekonomik Büyüme İlişkisi
}

\section{Energy Security of the European Union: The Relationship between Energy Import Dependency and Economic Growth}

\section{Serap ELÜSTÜ1 10}

\section{Öz}

Enerji piyasasının coğrafi koşullar nedeniyle oligopolistik bir yapıya sahip olması, bazı ülkeler için enerji ürünlerinin ithal edilmesini zorunlu kılmaktadır. Özellikle Avrupa Birliği, politik açıdan riskleri olan Rusya ve MENA (Orta Doğu ve Kuzey Afrika) bölgesi ile bağımlılığa ulaşan önemli enerji ilişkilerine sahiptir. Enerji güvenliğini aksatan bu durum, $A B$ için ekonomik açıdan risk oluşturmaktadır. Çalışmada $A B^{\prime} y e$ üye ve aday ülkelerin 2014-2018 dönemi petrol ve petrol ürünleri, doğal gaz, katı yakıt ithalatı ve enerji ithalatı bağımlılığının ekonomik büyüme ile ilişkisi panel veri analizi ile araştırı maktadır. Modele yönelik temel varsayım testlerinin sonucunda Driscoll-Kraay tahmin modelinin kullanılması uygun bulunmuştur. Bulgular, $A B$ ülkelerinin petrol ve petrol ürünleri ithalatının ekonomik büyümeleri üzerindeki etkisinin istatistiksel olarak anlamlı ve pozitif; enerji ithalatı bağımlılığının ise ekonomik büyümeleri üzerinde istatistiksel olarak anlamlı ve negatif yönlü olduğu şeklindedir. Doğal gaz ve katı yakıt ithalatının ekonomik büyüme üzerindeki etkisi ise istatistiksel olarak anlamsız bulunmuştur. Petrol ve petrol ürünleri ithalatının ekonomik büyüme ile aynı yönde hareket etmesi, Avrupa Birliği'nde GSYiH'nin büyük kısmının hizmetler sektörüne bağlı olması, hizmetler sektörünün en büyük parçasını ise petrol ve petrol ürünlerinin yoğun olarak kullanıldığı ulaştırma sektörünün oluşturması ile açıklanabilir. Enerji ithalatı bağımlılığı ise beklendiği üzere ekonomik büyümeyi olumsuz yönde etkilemektedir. Çalışma sonucuna göre $A B^{\prime}$ de yenilenebilir enerji kullanımı, enerji verimliliğinin artırıması gibi enerji ithalatı bağımlılığını azaltıcı politikaların reel GSYIH'yi artırıcı etki yaratması beklenmektedir. Enerjinin ithal edildiği kaynakların çeşitlendirilmesinin de, ihracatçıdan kaynaklanan tedarik risklerini aza indirmesi ve böylece enerji güvenliğini olumlu etkilemesi öngörülmektedir.

Anahtar kelimeler: Avrupa Birliği, Enerji ithalatı bağımlılığı, Enerji güvenliği, Ekonomik büyüme, Panel veri analizi

JEL Sınıflandırması: Q43, O47, 052

\section{ABSTRACT}

Energy markets have an oligopolistic structure based on global geographic conditions, which necessitates the import of energy

1Doktora Öğrencisi, İstanbul Üniversitesi, Sosyal Bilimler Enstitüsü, İktisat Anabilim Dalı, İstanbul, Türkiye

ORCID: S.E. 0000-0002-1225-3641

Sorumlu yazar/Corresponding author: Serap ELÜSTÜ,

İstanbul Üniversitesi, Sosyal Bilimler Enstitüsü, İktisat Anabilim Dalı, İstanbul, Türkiye

E-posta/E-mail: serapelustu@gmail.com

Başvuru/Submitted: 24.05 .2021

Kabul/Accepted: 03.06 .2021

Atıf/Citation: Elustu, S. (2021). Avrupa Birliği'nin enerji güvenliği: Enerji ithalatı bağımllığı ve ekonomik büyüme ilişkisi. Istanbul iktisat Dergisi - Istanbul Journal of Economics, 71(1), 133-162.

https://doi.org/10.26650/ISTJECON2021-942116 
products. Having a robust energy dependency on the Russian Federation and the Middle East and North African (MENA) region renders the European Union (EU) vulnerable in terms of both energy security and trade. This study analyzes the relationship between economic growth and energy import dependency, coupled with the import of oil and petroleum products, natural gas, and solid fuels in EU member and candidate countries between 2014 and 2018 through panel data analysis using the DriscollKraay estimator. Key findings reveal that the effect of natural gas and solid fuel imports on economic growth is statistically insignificant, whereas the effect of oil and petroleum product imports on economic growth is statistically significant and positive and the effect of energy import dependency on economic growth is statistically significant and negative. Oil and petroleum products are mostly used in transportation, and services have the highest share in the EU's gross domestic product (GDP); thus, the use of oil and petroleum products in the EU supports economic growth. The use of oil and petroleum products depends on imports, as the EU does not have sufficient internal sources. Increased energy efficiency and use of renewable energies may decrease energy import dependence and reduce the use of non-renewable energy products procured from external suppliers. If importing is a mandate, then diversifying exporters could minimize the risk of arising shortages from suppliers.

Keywords: European Union, Energy import dependency, Energy security, Economic growth, Panel data analysis

JEL Classification: Q43, O47, 052

\section{EXTENDED ABSTRACT}

Energy is one of the key inputs of industrialized economies in terms of manufacturing and services; however, global energy resources are unbalanced. In particular, while the MENA region has rich resources, Europe's energy is largely procured through imports. The import of energy products creates dependence on exporters that affect importing countries' economic outlook. This study investigates the relationship between energy and economic growth by examining energy import dependency in the EU using data from 2014 to 2018. In the literature, researches are usually regarding the relationship between energy and economic growth generally focuses on energy consumption. In contrast, energy import is used as an independent variable for this study to investigate energy dependency in the $\mathrm{EU}$, in substitution for consumption. The findings are expected to offer valuable insights into the economic risk of European countries regarding the use of imported nonrenewable energy products when such use cannot be reduced.

This study applies a panel data analysis of EU member and candidate countries. The real GDP (US\$) data is obtained from The World Bank; the energy import dependency index (\%) and imports of oil and petroleum products (gross ton), natural gas (million cubic meter), and fossil fuel (gross ton) are obtained from Eurostat, and all of the variables are assessed in logarithmic form. Due to missing 
data for Cyprus, Malta, and Serbia, 28 countries are included in this analysis. The first step investigates whether the model includes time or unit effects. The result of the test of a maximum likelihood indicates that the model includes only unit effect. Next, to determine whether to use a fixed or random effect model, a Hausman Test (1978) is applied, revealing that the appropriate model for this study is a fixed effect model. In the analysis, tests are required for assumptions. A Modified Wald Test (Greene, 2020) for heteroskedasticity, a Durbin-Watson Test of Bhargava, Franzini, and Narendranathan (1982) and a Baltagi-Wu Locally Best Invariant Test (1999) for autocorrelation, and a Pesaran Test (2004) for cross-sectional dependence are used for testing the key assumptions. The test results indicate that the model has heteroskedasticity, autocorrelation, and cross-sectional dependence, necessitating the use of robust estimators to estimate the model. The standard errors estimator proposed by Driscoll and Kraay (1998) is used in this analysis.

According to the results of the Driscoll and Kraay Standard Errors Estimator (1998), the overall F-Test is significant and the model is statistically significant. T-test results indicate that the energy import dependency index and oil and petroleum product imports variables are significant but natural gas and fossil fuel imports are insignificant at the level of 0.05 . The relationship between oil and petroleum product imports and real GDP is positive, and when oil and petroleum product imports increase, real GDP increases as well. A $1 \%$ increase in the import of oil and petroleum products correlates to a $0.44 \%$ increase in real GDP in EU countries. As expected, the relationship between energy import dependency and real GDP is negative; a $1 \%$ increase in energy import dependency decreases real GDP by $0.02 \%$. Based on the vulnerability generated by such dependency, increase in energy import dependency results in decreased economic growth in the EU.

Energy import dependency is one of the main concerns of the EU in recent years, as it renders EU countries more vulnerable to external shocks. Although the use of renewable energy resources has increased, non-renewable fuels are still used by a majority. This study investigates whether the import of non-renewable energy resources and energy import dependence affect economic growth using panel data analysis. The results of the Driscoll and Kraay Standard Errors Estimator 
(1998) indicate that energy import dependency lowers real GDP and oil and petroleum imports support economic growth. In the EU, oil and petroleum products are mainly used in transportation, and the service sector has the highest share of the real GDP; hence, the EU should develop policies to decrease crude oil consumption, particularly in the transportation sector. Advocating and legislating increased renewable energy products and increased energy efficiency would also be beneficial in this regard. Finally, diversifying the sources of oil and petroleum imports would minimize the risk of price that dependent countries (political, geographical etc.) rely on in terms of potential shortages in the EU. 


\section{Giriş}

Sanayileşme sürecinde enerji kullanımının artması, ancak kullanılan enerji kaynaklarının yalnızca belirli bölgelerden elde edilebilmesi, birçok ülkede enerji ithalatının artmasına neden olmuştur. Enerji ithalatındaki ve sanayileşmedeki artışla birlikte, günümüzde GSYiH ile enerji arasındaki karşılıklı ilişkiyi araştıran çalışmalara yer verilmekte; enerji güvenliği ve enerji ürünleri kullanımında dışa bağımlılık, bu konuların başında gelmektedir. Özellikle Avrupa ülkeleri için enerji ithalatına bağımlılık, enerji güvenliği açısından önemli bir tehdit olarak değerlendirilmekle birlikte, bu bağımlılığın azaltılmasına yönelik önlemler gündeme getirilmektedir. Bu önlemlerin başında enerji kaynaklarının çeşitlendirilmesi ve yenilenebilir enerji kullanımı gelmektedir.

Enerji sektöründe özellikle yenilenebilir enerji kullanımının enerji ithalatına bağımlılığı azaltması beklense de, çeşitli avantajları nedeniyle fosil yakıtların kullanımının hala oldukça yoğun olması, Avrupa ülkeleri için enerji tedarikinin güvenlik endişesi taşıyan bir konu olarak varlığını sürdürmesine neden olmaktadır. Ham petrol ve ürünleri, petrolün çok yönlülüğü ve ulaştırma sektörü için en uygun enerji türü olması nedeniyle enerji güvenliği açısından en önemlisidir. Doğal gaz, maliyeti uygun ve temiz bir enerji ürünü olması nedeniyle önem kazanmaktadır (Khatib, 2000, s. 119). Katı yakıtlar ise, küresel ısınma ve çevre kirliliği gibi endişeler yaratmasından dolayı kullanımı giderek azalsa da hala diğerlerine göre erişilebilirliğinin daha yüksek olması avantajını taşımaktadır (Martins, Felgueiras, Smitkova ve Caetano, 2019, s. 964). Bu avantajlar, fosil yakıtların Avrupa Birliği tarafından ithalatını gerekli kıldığı için, olası bir ekonomik, askeri veya politik bir sorun, enerji tedarikinde kesintiler veya bozulmalara yol açarak, ekonomik göstergeleri olumsuz etkileme riski taşımaktadır.

Bu çalışmada, Avrupa Birliği'nin enerji ürünleri ithalatına olan bağımlılığının ekonomik büyüme üzerindeki etkisi araştırılmaktadır. Yenilenemeyen enerji ürünleri olarak gruplandırılan "petrol ve petrol ürünleri, doğal gaz ve katı yakıt" ithalatının ekonomik büyüme üzerinde yaratabileceği etkiler panel veri analizi ile araştırılmaktadır. Analize Avrupa Birliği'ne üye ülkelerin yanında, aday ülkeler de 
dahil edilmektedir. Söz konusu enerji ürünlerinin yanı sıra, Avrupa Birliği'nin enerji ithalatı bağımlılık endeksi de bağımsız değişken olarak analize dahil edilmiştir. Literatürde çoğunlukla "enerji tüketimi" veya "enerji kullanımı" olarak kullanılan enerji değişkeninin, bu çalışmada "enerji ithalatı" şeklinde kullanılmasının, enerjide dışa bağımlılığın etkisini daha iyi yansıtması beklenmektedir.

\section{Avrupa Birliği'nde Enerji Sorunları}

\subsection{Enerji Güvenliği}

Enerji kaynakları dünya genelinde eşit bir şekilde dağılmamakta; özellikle petrol ve petrol kadar olmasa da doğal gaz birkaç bölgede yoğunlaşmaktadır. Basra Körfezi'ndeki petrol rezervlerinin yoğunluğu, her zaman tedarikin devamlılığı için endişe oluşturmuştur. Ülkelerin çoğu, ekonomik sorunlara yol açan fiziksel bozulmalarla birlikte 1970 'lerde ve 1980'lerin başında petrol kıtlıkları ve yüksek fiyatlarla karşı karşıya kalmıştır. Enerji ithalatçıları bu tür tecrübelerin tekrarı konusunda endişe etmektedirler (Khatib, 2000, s. 118).

Enerji güvenliğinin bir gündem konusu haline gelmesindeki önemli olaylardan ilki, I. Dünya Savaşı sırasında Winston Churchill'in, İngiliz donanması gemilerinin yakıtını, Alman gemilerinden daha hızlı olması için, kömürden petrole çevirmek istemesi olmuştur. Bu durum, Kraliyet Donanması'nı Galler kömürünü kullanmak yerine, İran'dan gelen güvencesiz petrole güvenmek durumunda bırakmıştır. Böylece enerji güvenliği ulusal bir sorun haline gelirken, Churchill'in ise cevabı: "Petrolün güvenliği ve emniyeti yalnızca çeşitliliktedir" olmuştur (Yergin, 2006, s. 69). Bu cevap, günümüzde enerji tedarikinin sağlandığı ülkelerin çeşitlendirilmesi veya farklı enerji türlerinin kullanımı (güneş, rüzgar enerjisi) gibi enerji güvenliğini artırmaya yönelik çözümlerle paraleldir.

Enerji güvenliği tarihsel süreçte çeşitli olaylarla yeniden gündeme gelmiş, dış politikaların önemli bir unsuru olarak tartışılmaya başlanmıştır. 1948-1949 döneminde ilk Arap-İsrail savaşında Irak petrolünü Hayfa'ya taşıyan boru hattının kapatılması ve Trans-Arap Boru Hattı'nın onayında gecikme; 1951-1953 
döneminde İran başbakanı Muhammed Musaddık tarafından İran petrol tesislerinin millileştirmesi ve ardından kapatılması; 1956'da II. Arap-İsrail Savaşı sırasında Mısır'a yapılan saldırıda Süveyş Kanalı'nın kapatılması ve Suriye'nin Mısır'la dayanışma göstermek için Irak boru hatlarını bombalayarak Avrupa'da petrol kıtlığı tehlikesine yol açması ve 1967'de Arap petrolü ambargosu gibi önemli krizler yaşanmışıtır (Isaawi, 1978, s. 3-5). Özellikle Yahudilerin savaşlarda aldığı galibiyetler sonucu İsrail'in kurulması ve bunun yanı sıra Orta Doğu'da topraklarını genişletmesinin sebebi olarak Batılı ülkelerin Yahudiler'e destek vermesini gören OPEC (Petrol İhraç Eden Arap Ülkeleri Teşkilatı) ülkeleri, petrole bağımlı durumdaki bu ülkeleri cezalandırmak amacıyla petrolü bir koz olarak kullanmıştır (Yılmaz ve Kalkan, 2017, s. 182).

1973 ve 1979 yıllarında iki büyük petrol krizi yaşanmıştır. 1973 yılııı Ocak ayında, Mısır ve Suriye tarafından İsrail'e karşı askeri bir saldırı düzenlenmiş; OPEC, İsrail sempatizanı olduğunu düşündüğü ülkelere ambargo uygulamıştır. OPEC üreticileri, 1970'lerin başında uzun dönemli sözleşmelere bağlı olarak sürdürdüğü istikrarlı petrol fiyatlarından vazgeçip, tek taraflı olarak daha yüksek fiyatlardan petrol ihraç etmeye başlamışlardır. Askeri çatışmanın üretim kesintilerine neden olduğu, bunun da petrol fiyatlarını yükselttiği iddia edilse de, söz konusu petrol krizinin altında siyasi-askeri bir kararın yattığı düşünülmektedir (Hamilton, 2003, s. 388; Barsky ve Kilian, 2002, s. 171). Bu krizden altı yıl sonra 1979 yılında, İran Şahı́nın İslami değerleri güçlendirmeye dayalı bir devlet kurmak için Fransa'da sürgünden dönen Ayatollah Khomeini tarafından devrilmesi ile oluşan siyasi paniğin yarattığı petrol fiyat artışı ikinci büyük petrol krizine yol açmıştır (Campbell, 2005, s. 92). Bu krizler petrol ithalatına bağımlı ülkelerin ekonomik büyüme oranlarında önemli daralmalar meydana getirmiş̧ir. Örneğin 1973 yllı AB büyüme oranı \%6 iken, 1974 döneminde \%3.1'e düşmüş; 1975 yllında petrol krizinin süren etkisiyle $A B$ ekonomisi \%0.6 daralmıştır (The World Bank, 2021). Enerji kullanımının ve özellikle enerjide dışa bağımlılığın ülkelerin ekonomik performanslarını etkilemesi nedeniyle, siyasi ve askeri sorunların enerji ithalatçısı ülkeler üzerinde önemli etkiler yarattığı görülmektedir.

Enerji güvenliği, 1970'lerin başında, özellikle OECD ülkelerindeki ve diğer başlıca petrol ithalatçısı ülkelerdeki petrol tüketimi ve ithalatına bağımlılığın 
azaltılması olarak görülmüş, ancak petrol ve diğer enerji piyasalarındaki önemli değişiklikler manzarayı değiştirmiştir. Rezerv ve stokların bulunmasıyla tedarikçiler artmış ve kartel anlaşmaları yerine piyasa gücü tarafından belirlenen fiyatlar esnek ve şeffaf hale gelmiş; küresel gerilim ve bölgesel çatışmalar azalmış ve ticaret gelişerek daha serbest hale gelmiştir. Tedarikçiler 1980'lerin başından itibaren petrol yaptırımları uygulamamıs, dünyanın herhangi bir yerinde reel kıtlıklar da yaşanmamıştır. Hatta Birleşmiş Milletler ve diğer aktörler, dünya petrol ticaretini etkilemeden veya kıtlık yaratmadan bazı petrol tedarikçilerine yaptırım uygulamışlardır (Khatib, 2000, s. 113). 1970'lerde ve 1980'lerin başında, OPEC ülkelerinden yapılan petrol ithalatına bağımlılığın yüksek olması ve yüksek yakıt fiyatlarının enerji yoğun endüstrilerde maliyet yapısını değiştirip rekabet edebilirliği azaltması nedeniyle, enerji verimliliği politikaları OECD ülkelerinde geniş çapta kabul görmüştür. Enerji verimlilik politikalarındaki kamu yararı, 19861999 arasında dünya enerji fiyatlarının azalmasıyla, birçok OECD ülkesinde enerji ithalatına azalan bağımlılıkla ve Kyoto Protokolü'nün uygulanmasına yönelik müzarekelerin yavaşlamasıyla, birçok OECD ülkesinde düşmüştür (Jochem, 2000, s. 207). Fosil yakıtların uluslararası ticaretteki rolünün yükselmeye devam ettiği Çin ve Hindistan'ın enerji tüketimindeki büyük artış nedeniyle, dünya enerji dengesinde de değiş̧iklikler yaşanmaktadır. Bu iki ülkede son yıllarda yaşanan güçlü ekonomik büyüme, artan ithalatla karşılanan enerji taleplerinde de önemli artışlar meydana getirmiştir (Bartoletto, 2012, s. 323). Hızla sanayileşen Çin ve Hindistan'ın artan ve arzın karşılamakta yetersiz kaldığı enerji talebi nedeniyle, enerji fiyatlarının gelecekte de daha ucuz olmayacağı beklenmektedir (Ayres ve ark., 2007, s. 638). Bu durum, AB'nin enerji güvenliği riskini artırmaktadır.

Avrupa'nın enerji politikasındaki gelişmeler uzun bir süre; yükselen enerji bağımlılığı, yükselen fiyatlar ve $A B$ genişlemesi, gaz tedarikinde bozulmalar çerçevesinde gerçekleşmiştir. Bunun sonucu olarak Avrupa Komisyonu "enerji güvenliği" konusunda politikalar belirlemeye başlamıştır. Özellikle AB'nin 15 ülkeden 27 ülkeye genişlediği 2004-2007 sürecinde, AB'ye yeni katılan ülkelerin, Rusya gazına yüksek bağımlılığı ile Rus enerjisi ve Rus dış politikasına dair geçmişe dayalı şüphelerin, Avrupa Komisyonu'nun bu konudaki girişimlerine hız vermesine katkı sağladığı düşünülmektedir. Yükselen fiyatlar ve $A B$ genişlemesi süresince 
Birliğe daha yüksek enerji ithalatı bağımlılığı olan ülkelerin dahil olması ile, Rusya'nın bir garantörden ziyade, $A B$ için bir "enerji güvenliği tehdidi" olduğu fark edilmiştir (Maltby, 2013, s. 435-441). 2005 Haziran'da Berlin'deki Avrupa ile Rusya ilişkileri üzerindeki görüşmede Rus siyasetçi Dmitry Rogozin, Avrupa'da Rusya hakkında "petrol fobisi" geliştiğini belirtmiştir. Bu açılamayla Rogozin, Avrupa'nın, enerji ithalatında Rusya'nın payının büyümesini bir tehlike olarak algıladığını kast etmektedir. Rusya, Avrupa piyasalarının en büyük tedarikçisi olduğu için, Avrupa'nın Rusya'ya yönelik petrol ve gaz "fobisinin" her ikisine de sahip olduğu görülmektedir. 1970'ler 1980'lerdeki SSCB ile ilişkilere de dayanarak, AB'nin Rusya'ya olan enerji ithalatı bağımlılığı nedeniyle, Rusya'nın enerji ihracatını kendilerine karşı olumsuz yönde baskı uygulamak için siyasi bir silah olarak kullanmasından endişe edilmiştir. Bu tabloda, Avrupalı yerli petrol ve gaz üretimi düşmeye, petrol ve gaz yakıtı ithalatı yükselmeye devam ederken, "Avrupa'nın Finlandiyalılaşması ${ }^{1 "}$ kaçınılmazdır . Bu fobi, Almanya'nın da dahil olduğu çeşitli Avrupa ülkelerindeki kamu söylemlerinde gerçek bir sorun haline gelmiş ve Brüksel'de AB düzeyinde politik ortama yayılmaya başlamışırı (Hill, 2005). Bu gibi endişeler, $A B^{\prime} y i$ Rusya'dan sağlanan enerjiye alternatif olabilecek ülke arayışlarına yöneltmiştir. Özellikle coğrafi olarak da AB'ye yakınlığı bulunan Rusya, başta Kırım sorunu olmak üzere sık sık $A B$ ülkeleri ile diplomatik problemler yaşamaktadır. Bu durumun enerji güvenliği için gelecekte tehdit oluşturma olasılığına rağmen, Rus ekonomisinin enerji ihracatına bağımlılığı, bu ticaretin her iki tarafının da atacakları sert adımları kısıtlamaktadır. Ancak $A B$ ülkeleri Rus enerji ürünlerini toplu olarak satın almadıkları ve her birinin Rus enerjisine bağımlılık seviyesi farklı olduğu için, Rusya özellikle daha küçük ve doğu Avrupa'da yer alan $A B$ ülkelerini sindirmek için enerji gücünü kullanabilmektedir (Korteweg, 2018, s. 30).

Alternatif enerji ihracatçısı arayışlarının bir cevabı Norveç'tir. Aslında Norveç'in AB'nin petrol politikasında önemli bir konuma gelmesi 1982 yllında gerçekleşmiştir. Soğuk Savaş'ın iki tarafı olan Rusya ve ABD arasındaki gerilim, ABD'nin 1982 yılında

\footnotetext{
1 "Finlandiyalılaşmak" terimi, Soğuk Savaş döneminde Finlandiya'nın Sovyetler Birliği ile "dostça" ilişkiler sürdürüyor gibi görünerek, esasen Sovyetler Birliği tarafından egemenliğinin azaltılmasına atıfta bulunmak için kullanılmaktadır. Bu kavram, Batı Avrupalıları sovyet tehdidine karşı uyarıda bulunmak amacıyla kullanılan bir metafordur (Berndtson, 1991; Laqueur, 1977).
} 
Batı Avrupa ülkeleri ile bir gaz anlaşması yaparak Rusya'ya bağımlı hale gelmesini ve bu bağımlılığın Rusya'nın eline koz vermesini ve gelecekte yaşanabilecek siyasi bir krizde bu ülkelerin baskı altında kalmasını önlemek amacıyla Norveç'i Sovyet gazına ikame olması için gaz üretimini artırmaya çağırmıştır. Bu dönemden itibaren Norveç, AB'nin önemli bir ihracatçısı konumundadır (Harbo, 2008, s. 5). Ancak verilere bakıldığında $A B^{\prime}$ nin Rusya'ya olan enerji ithalatı bağımlılığını azalttığını söylemek pek mümkün görünmemektedir. UN Comtrade (2021) verilerine göre, Rusya ve Norveç'ten ithal edilen 27 kodlu enerji ürünlerinin ithalat değeri birbirine yakınken, 2018 yılında Rusya'dan ithal edilen enerji ürünlerinin değeri Norveç'in iki katıdır.

Enerji ithalatına olan bağımlılık, "enerji güvenliği"ni azaltmaktadır. Günümüzde petrol ihracatı yapan başlıca ülkeler iç savaş ve terörizm gibi ulusal siyasi karışıkıklara maruz kalmaktadır. OPEC'in regülasyon gücü de düşüktür. Siyasi nedenlerle yaşanan tedarik kesintileri yalnızca Orta Doğu'ya ait değildir. Asya (Endonezya), Afrika (Nijerya, Sudan), Latin Amerika (Venezuela, Bolivya, Kolombiya, Ekvador), oldukça hassas bölgelerdir. Bu nedenle yerel kesintiler, yetersiz yatırım ve olası yüksek fiyat talepleri beklenebilir. Bu durum, petrol ithalatı bağımlılığı açısından ciddi bir sorundur (Chevalier, 2006, s. 12). Doğal gaz tedarikinde yaşanan sorunlar elektrik kıtlıklarını da beraberinde getirme riski yaratır. Elektrik üretiminde doğal gaza olan bağımlılığın artması nedeniyle, doğal gaz ithalatında yaşanan problemler domino etkisi yaratarak, elektrik talebinin karşılanması konusunda da risk oluşturur. Doğal gaz tedarikindeki olası bir kesinti, doğal gazla çalışan elektrik santrallerini talebe cevap veremez hale gelebilir (Khatib, 2000, s. 125).

\subsection{Enerji İthalatı Bağımlılığı}

Enerji bağımlılığı ile, rekabet gücünde ve GSYiH'de kayıplar, enflasyonist baskı ve ticaret dengesi bozulmalarına dönüşecek enerji fiyat şokları veya enerji tedarikinde bozulmalara karşı üye ülkelerin kırılganlıkları ifade edilmektedir. Enerji bağımlılığı göstergeleri, enerji bağımlılığının temel boyutlarını tanımlamaktadır. Bu göstergeler şu şekilde açıklanmaktadır (Canton ve ark., 2013, s. 5-6): 
- Enerji Tedarikinin Güvenliği: Avrupa Komisyonu'nun tanımına göre enerji güvenliği, "enerji kaynaklarının çevresel kaygılara da uyarak, uygun fiyatlarla kesintisiz ulaşılabilirliği"ni ifade eder. Enerji kaynaklarının ülkeler arasında eşitsiz dağılımı, önemli enerji ithalat bağımlılıklarına neden olmaktadır. Enerji ithalatına olan bağımlılığın artması; ithal edilen ve dengesiz dağıtılmış olan enerji kaynaklarına mecbur kalınması, enerji üreten ve geçiş ülkeleri olan ülkelerin siyasi istikrarsızlığı, enerji kaynakları üzerinden küresel rekabet, kazalar, doğal afetler ve terörizm gibi enerji güvenliğine yönelik tehditler oluştumaktadır. Enerji ürünleri ithalatında kaynakların çeşitlendirilmesi, $A B$ açısından değerlendirilirse, üye devletlerin enerji şoklarına direncini artıracak ve sonuç olarak enerji ithalat bağımlılıklarını azaltacaktır.

- Enerji ve Karbon Yoğunluğu: Enerji yoğunluğu, birim GSYiH başına düşen enerji kullanım miktarını ifade eder ve enerji verimliliğini ölçmenin en iyi yollarından biridir. Enerji yoğunluğunun azaltılması ve enerji verimliliğinin geliştirilmesi, ekonomik ve çevresel faydalar getirirken, enerji ithalatı bağımllığını azaltır.

- Enerji Ürünlerinin Ticarete Katkısı: AB'nin enerji ihtiyacı için yüksek enerji ithalatı bağımlılığı, cari işlemler hesabındaki dengesizlikler üzerindeki sonuçları göz önüne alındığında, enerji ürünlerinin ticarete katkısı ile karşılaştırılarak değerlendirilmelidir. Bir ülkenin potansiyel kırılganlığı, eğer ülke hem enerji bazlı ticaret açığı hem de cari işlemler açı̆̆ı sergilerse daha fazla olacaktır.

Enerji ithalatı bağımlılığı politika yapıcılar için önemlidir, çünkü enerji tedarikini; kendi kontrolleri dışında belirlenen faktörlerin yarattığı küresel fiyat oynaklığına, ekstrem durumlarda fiziksel tedarik kesintileriyle sonuçlanabilecek başlıca ihracatçıların piyasa gücüne, ithalat rotası boyunca, transit ülkeler dahil kesintilere maruz kalma faktörlerine karşı kırılgan yapar (Cherp ve ark., 2012, s. 337). Cirovic, Makajic-Nikolic, Petrovic, Vujosevic ve Kuzmanovic (2015), Hırvatistan'ın AB'ye katıldığı son genişleme döneminde yaptıkları ve olası bir enerji kıtlı̆̆ı durumunda AB ülkelerinin risk durumlarını 1998-2010 verilerini dikkate alarak FMEA yöntemiyle analiz ettikleri çalışmalarında, Avrupa'nın ikinci en büyük petrol ithalatçısı olan 
Hollanda'nın, enerji ithalatında kesinti halinde en büyük krizi yaşayacak $A B$ üyesi ülke olduğunu belirtmişlerdir. Çalışmada Hollanda'yı Avrupa'nın birinci, dünyanın ise dördüncü en büyük petrol ithalatçısı ülke olan Almanya izlemektedir. Illk beşte yer alan diğer ülkeler sırasıyla Belçika, İtalya ve Fransa olmuştur. Çalışmada AB bir bütün olarak risk analizinde altıncı sırada yer almaktadır. Çalışmanın yapıldığı dönemde Birleşik Krallık'ın da AB üyesi olması ve Danimarka ile birlikte kendi petrol üretimlerini gerçekleştirmelerini sağlayacak petrol kaynaklarına sahip ülkeler olmaları dışında, diğer tüm $A B$ üyesi ülkeleri petrol ithalatına bağımlı durumdadır. Danimarka coğrafi konumunun da getirisiyle petrol üretimini kendi yapabildiği ve tüketimini karşılayabildiği için bu listede son sıradadır.

\section{Grafik 1. AB Üye ve Aday Ülkelerin Enerji İthalat Bağımlılıkları (2018) (\%)}

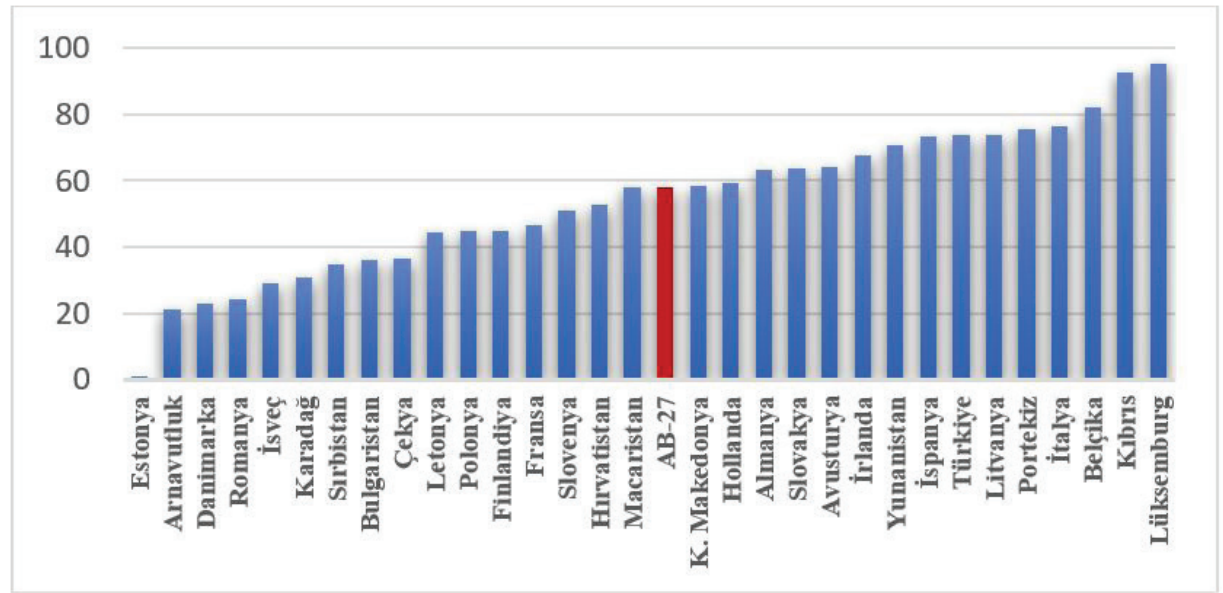

Kaynak: Eurostat

Grafik 1'de AB'ye üye ve aday ülkelerin enerji ithalat bağımlılıkları verilmiştir. 2018 verilerine göre enerji ithalatına bağımlılı̆ı en yüksek $A B$ ülkeleri Lüksemburg, Kıbrıs ve Belçika iken; aday ülkelerden ise Türkiye'nin, enerji ithalatına bağımlılığı en yüksek ülke olduğu görülmektedir.

Eurostat (2021) verilerine göre ithalat bağımlılığı en yüksek enerji ürünü petrol ve petrol ürünleri olarak verilmektedir. Petrol ve petrol ürünlerini sırasılla doğal gaz ve katı yakıtlar izlemektedir. Enerji ürünlerinin toplam ithalat bağımlılığına 
bakıldığında, katı yakıtlara olan ithalat bağımlılığın, toplam ithalat bağımlılığının altında olduğu belirtilmiştir. Bu durum, katı yakıtların erişilebilirliğinin görece daha kolay olması nedeniyle diğer enerji ürünlerine göre, hem ayrı ayrı hem de toplam olarak, ithalat bağımlılığı daha düşük olması şeklinde açıklanabilir.

Bir ülkenin enerji bağımlılığı, daha önce tanımlandığı üzere, bir birim GSYiH üretimi için gerekli olan enerjiyi ifade eden "enerji yoğunluğu" ile ölçülebilir. Enerji verimliliği artışı veya üretimdeki yapısal değişiklikler, enerji yoğunluğunu ve dolayısıyla enerji bağımlılığını azaltmaktadır (Chevalier, 2006, s. 6). Enerji ve ekonomik büyüme arasındaki ilişkiyi ölçmek için, enerji yoğunluğu ve enerji verimliliğini dikkate almak gerekir. Belirli bir gelir seviyesinden sonra enerji yoğunluğunun giderek azalması, ekonomik sistemin verimliliğindeki artışla açıklanabilir. Enerji yoğunluğu eğrisi, ekonomik büyümenin durumuna bağlı olarak değişen bir trendi gösterir: Eğer enerji tüketimi yalnızca modern enerjiyi içeriyorsa, eğri endüstrileşme evresi boyunca hızla yükselir ve endüstriyel olgunluk aşamasında zirve yapar, ardından artan gelirin etkisiyle, enerji yoğunluğu, yüksek katma değer içeren hizmetlerin artışına bağlı olarak düşme eğiliminde olur. Geçmiş örnekler dikkate alındığında, ekonomik kalkınmanın ilk aşamalarında tarımdan ağır sanayiye, daha sonra aşamalarda ise hizmetler sektörü ve hafif sanayiye dönülmektedir. Bu birbirinden farklı sektörlerin enerji yoğunlukları da farklıdır. Ekonomik kalkınmanın ilk aşamalarında çıktı başına kullanılan enerji miktarında yükseliş olurken, daha sonraki aşamalarda bu miktar düşüş göstermektedir (Bartoletto, 2012, s. 314). 


\section{Grafik 2. AB-27 ve AB Aday Ülkelerinin Enerji Yoğunlukları (2018) (Zincirlenmiş Hacim Endeksiyle GSYïH İçindeki Payı)(Bin Euro Başına KGOE)}

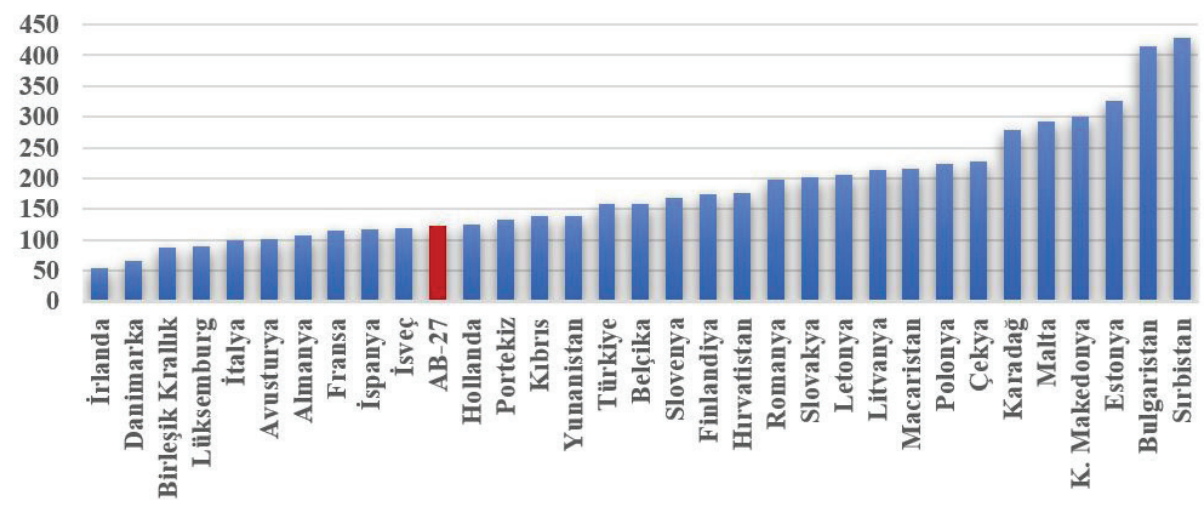

Kaynak: Eurostat

Grafik 2'de AB'ye üye ve aday ülkelerin 2018 yılındaki enerji yoğunlukları verilmiştir. Özellikle AB'nin beşinci ve altıncı genişleme döneminde Birliğe katılan ülkelerin enerji yoğunluklarının $A B$ ortalamasına göre oldukça yüksek olduğu görülmektedir. Bu tablo, AB'ye sonradan katılan ülkelerin, Birliğin bir bütün olarak enerji bağımlılığının yükselmesinin sebeplerinden biri olduğuna işaret edebilir. Benzer şekilde AB'ye aday ülkelerden Kuzey Makedonya, Sırbistan ve Karadağ'ın da enerji yoğunlukları, ortalamanın oldukça üzerindedir.

\section{Literatür Taraması}

Enerji ve ekonomi arasındaki ilişkiyi araştıran çalışmalarda enerjiyi temsil eden çeşitli değişkenler kullanılmaktadır. Literatürde yoğun olarak "enerji tüketimi" değişkeninin kullanıldığı görülmekte olup, bunun yanı sıra enerji ithalatı, enerji yoğunluğu gibi göstergeler de ekonomik büyümeyi açıklamak üzere kullanılabilen değişkenler arasındadır. Çeşitli ülkeler ve topluluklar için yapılan bu çalışmaların hem ithalatçı, hem de ihracatçı ülkeler açısından değerlendirmeleri bulunmaktadır. Bu çalışmada olduğu gibi ithalatçı perspektifinden enerji ürünleri ve ekonomik büyüme arasındaki ilişkiyi araştıran çalışmalarda farklı ülkeler ve modellere yer 
verilmektedir.

Streimikiene ve Kasperowicz (2016), 1995-2012 dönemi için Vişegrad ülkeleri ve $14 A B$ ülkesini içeren ve enerji tüketimi ile ekonomik büyüme arasındaki uzun dönemli ilişkiyi panel birim kök testi, panel eşbütünleşme testi, tam değiştirilmiş en küçük kareler (FMOLS) ve dinamik en küçük kareler yöntemi (DOLS) ile araştırmışlardır. Çalışmada enerji tüketimi ve ekonomik büyüme arasındaki ilişkinin istatistiksel olarak anlamlı ve pozitif olduğu sonucunu elde etmiş; çalışmanın temel bulgusu olarak da enerji tüketiminin, ekonomik büyümenin ayrılmaz bir parçası olduğunu ve bu nedenle $A B$ ülkelerinin ekonomik büyümelerinin enerji bağımlı bir yapıda olduğunu ifade etmişlerdir. Yine Kasperowicz ve Štreimikienè (2016), 1995-2012 döneminde ekonomik büyüme ve enerji tüketimini Vişegrad Ülkeleri (Çekya, Macaristan, Polonya ve Slovakya) ve 14 "eski" AB üyesi ülkesi için karşılaştırmalı olarak bu kez panel en küçük kareler yöntemi ile ele aldıkları çalışmalarında enerji kullanımı ve ekonomik büyüme arasında pozitif bir ilişki olduğunu; Vişegrad ülkelerinde enerji tüketiminin ekonomik büyümeye olan pozitif etkisinin $A B$ ülkelerine göre daha etkili olduğunu ve gelişmekte olan ülkelerde enerji tüketiminin ekonomik büyüme için temel bir faktör olduğunu belirtmektedirler. Ayrıca enerji tüketimindeki \%1'lik artışın Vişegrad ülkelerinde ekonomik büyümeyi \%0.19; AB-14 ülkelerinde ise \% 0.066 artırdığının belirtildiği çalışmada, Vişegrad ülkelerinde ekonomik büyümenin enerjiye daha fazla bağımlı olduğu sonucuna varılmıştır. Her iki çalışmanın da ekonomik büyüme ve enerji tüketimi açısından paralel bir bulguya sahip olduğu belirtilmektedir.

Örgün ve Pala (2017), 1996-2013 döneminde AB ülkelerindeki enerji tüketimi ve ekonomik büyüme arasındaki ilişkiyi panel veri ile araştırdıkları çalışmalarında, kısa vadede ticari açıklıktan ekonomik büyüme ve enerji tüketimine doğru tek yönlü ve enerji tüketiminden ekonomik büyümeye doğru tek yönlü nedensellik bulgusuna ulaşmıştır. Enerji tüketimi ve ekonomik büyüme arasında uzun dönemli nedensellik bulunamadığının belirtildiği çalışmada, bu sonuç $A B$ ülkelerinin enerjiye bağımlı olmalarına bağlanmaktadır.

Pirlogea ve Cicea (2012), 1990-2010 döneminde İspanya, Romanya ve AB'de enerji ve ekonomik büyüme ilişkisini karşılaştırmalı olarak incelediği çalışmalarında, 
$A B^{\prime}$ de yenilenebilir enerji ve petrol ürünlerine dayalı enerji tüketimi arasında uzun dönem dengesi olduğunu, petrol ürünlerine dayalı enerjinin hem $A B-27$ ülkeleri hem de İspanya ve Romanya için gözlemlendiğini belirtmiş, buna dayanak olarak ise petrolün enerji yoğun bir sektör olan ulaştırma için temel yakıt olması gösterilmiştir. Doğal gaz, petrol ürünleri ve yenilenebilir enerjinin GSYiH'yi etkileyen enerji tüketimi için temel kaynaklar olduğu Romanya'da, çoğunlukla enerji tüketimi ve büyüme arasında uzun dönem ilişkiler bulunmuştur. İspanya'da gaz ve petrol ürünleri ağırlıklı tüketimin uzun dönemde ekonomik büyümeyi hızlandırdığı bulgusuna ulaşılmıştır. Kısa dönemde ise Romanya'da yenilenebilir enerji-ekonomik büyüme ve İspanya'da doğal gaz-ekonomik büyüme ilişkileri dışında ilişki bulunamamıştır.

Marques, Fuinhas ve Tomas (2019), 1997-2015 döneminde 11 AB ülkesini kapsayan, Driscoll-Kraay tahmincisi kullanarak doğrusal olmayan ARDL modeli ile enerji verimliliği ile ekonomik büyüme ilişkisini araştırdığı çalışmasında, enerji verimliliği ve ekonomik büyümenin karşılıklı olarak birbirlerini pozitif yönde etkilediği sonucuna ulaşmıştır.

Georgantopoulos ve Tsamis (2011), dört Balkan ülkesi (Şu an AB üyesi olan Yunanistan, Bulgaristan, Romanya ve AB'ye aday olan Arnavutluk) için Johansen Eşbütünleşme Testi ve Granger Nedensellik Analizi ile 1980-2009 dönemini kapsayan ve enerji tüketimi ile GSYïH ilişkisini araştırdıkları çalışmalarında Bulgaristan ve Romanya'da enerji tüketiminin ekonomik büyümenin nedeni olduğu bulgusuna ulaşmıştır. Yunanistan'da bu nedensellik ekonomik büyümeden enerji tüketimine doğru bulunmuş, Arnavutluk için ise nedensellik ilişkisi bulunmamıştır.

Vlahinić-Dizdarević ve Žiković (2010), Hırvatistan'da 1993-2006 döneminde enerji ve ekonomik büyüme arasındaki nedensellik ilişkisini ele aldıkları çalışmalarında, enerji değişkenleri olarak endüstri ve hanelerde enerji tüketimi, petrol tüketimi, birincil enerji üretimi ve net enerji ithalatını kullanmışlardır. Analiz bulgularında Hırvatistan'da reel GSYIH ile enerji tüketimi, birincil enerji üretimi ve net enerji ithalatı arasında eşbütünleşme ilişkisi yer almaktadır. Yine 
analize göre, bir gecikmeli olarak reel GSYiH'deki \%1'lik artışın petrol tüketimini \%0.72 artırdığı; birincil enerji üretiminin GSYiH ile bir gecikmeli olarak pozitif ilişkisi olduğu ancak iki gecikmeli olarak negatif ilişkisi olduğu; net enerji ithalatının ise yine GSYiH ile ilişkili olduğu, reel GSYïH'deki \%1'lik artışın net enerji ithalatını birinci gecikmede \%2.35, ikinci gecikmede \%3.2 artırdığı bulunmuştur. Reel GSYiH ile endüstri ve hanehalkı nihai enerji tüketimi ise ikinci gecikmede kısa dönemli pozitif ilişkili bulunmuştur. Reel GSYiH'deki \%1'lik artış, nihai enerji tüketiminde hanehalkları için \%2.4 ve endüstri için \% 1.3 'lük bir artışa neden olmaktadır. Çalışmada tüm enerji değişkenleri için kısa dönem dinamikleri reel GSYIH'den enerjiye doğru olmak üzere aynı yönde gelişmektedir. Çalışmada bu durumun daha çok gelişmiş ülkelerde görüldüğü, ancak bir gelişmekte olan veya geçiş ekonomisi olarak tanımlanan Hırvatistan'ın bu açıdan gelişmiş ülkelerle aynı davrandığı belirtilmiştir.

Esen ve Bayrak (2017), 75 enerji ithalatçısı ülkeyi önce enerji bağımlılıklarına göre (\%50'den az ve fazla olarak) iki, ardından gelir gruplarına göre kendi içinde dört kategoriye ayırarak 1990-2012 döneminde enerji tüketimi ve ekonomik büyümeleri arasındaki uzun dönemli ilişkiyi panel veri yöntemiyle analiz etmişlerdir. Çalışmada enerji tüketimi ve ekonomik büyüme arasındaki uzun dönemli ilişkinin her ülke için istatistiksel olarak anlamlı olduğu, enerji kullanımının ekonomik büyüme için etkili bir değişken olduğu sonucuna ulaşılmıştır. Enerji bağımlılığı \%50'nin altında olan ülkelerde enerji tüketiminin ekonomik büyüme üzerindeki etkisinin bağımlılığın \%50'nin üstünde olduğu ülkelerden daha fazla olduğu; gelir seviyelerine göre ayrıldığında ise düşük gelirli ülkeler için ilişkinin istatistiksel olarak anlamsız olduğu, ancak diğer gelir grupları (düşük-orta, orta-üst, yüksek) için istatistiksel olarak anlamlı ve pozitif olduğu, bu etkinin ülkenin gelir seviyesi arttıkça azaldığı belirtilmiş, gerekçe olarak ise ülkenin gelişmişlik seviyesindeki artışın enerjiyi daha verimli kullanarak bir birim çıktıyı elde etmek için daha verimli enerji kullanabilmesi gösterilmiştir.

Beşer ve Öztürk (2020), 1986-2013 dönemini kapsayan ve panel veri modelini kullandıkları çalışmalarında, en çok petrol ithal eden eden 16 ülkeden 10 ülkenin petrol ithalatının, ekonomik büyümeleri üzerinde pozitif; petrol fiyatlarının ise 16 
ülkeden 13'ü üzerinde ekonomik büyümeye negatif etkisi olduğunu bulmuşlardır. Özata (2010), 1970-2008 döneminde Türkiye'de enerji tüketimi ve ekonomik büyüme ilişkisini incelediği çalışmasında, eşbütünleşme analizine göre enerji tüketimi, petrol tüketimi ve GSMH arasında uzun dönemli bir ilişki olduğunu, nedensellik analizinde ise $\% 5$ anlam düzeyinde GSMH'den enerji tüketimine doğru tek yönlü nedenselliğin olduğunu ve büyümenin enerji tüketimini artırdığını; \%10 anlam düzeyinde ise GSMH'den petrol tüketimine tek yönlü nedenselliğin olduğunu belirtmektedir. Aydın (2010), 1996-2004 ve 1980-2004 dönemlerinde Türkiye'de enerji tüketimi ve ekonomik büyüme ilişkisini en küçük kareler yöntemiyle araştırdığı çalışmasında, enerji tüketiminde \%1'lik artışın ekonomik büyümede \%1.03'lük artışa yol açacağı sonucuna ulaşmıştır.

Mucuk ve Uysal (2009), 1960-2006 dönemi Türkiye'de enerji tüketimi ve ekonomik büyüme arasındaki nedensellik ilişkisini gösteren çalışmalarında, enerji tüketiminden ekonomik büyümeye doğru tek yönlü nedensellik ilişkisi olduğunu ve enerji tüketiminin büyümeyi pozitif yönde etkilediğini belirtmektedir. Bozkurt ve Akan (2014), Türkiye için 1960-2010 dönemini kapsayan ve Johansen-Juselius Eşbütünleşme Analizi'ni kullandıklarını çalışmalarında enerji tüketimi ve ekonomik büyüme değişkenleri arasında uzun dönemli bir eşbütünleşme ilişkisi olduğu, enerji tüketiminde \%1'lik artışın ekonomik büyümeyi \%6.5 artırdığı bulgusuna ulaşmıştır.

Avrupa ülkelerinin yanı sıra petrol ithal edilen farklı bölgelerde enerji ve ekonomik göstergeler arasındaki ilişkiyi araştıran çalışmalar da bulunmaktadır. Matei (2017), 34 OECD ülkesini içeren ve 1990-2014 dönemini kapsayan ve dinamik panel veri analizini kullandığı çalışmasında, uzun vadede yenilenemeyen enerji tüketimi ile reel GSYIH arasında karşılıklı nedensellik ilişkisi olduğunu, eşbütünleşme analizine göre ise yenilenemeyen enerji tüketimindeki \%1'lik artışın, reel GSYïH'yi OECD-24 ülkelerinde \%0.82, OECD-15 ülkelerinde \%0.90 artırdığı bulgusuna ulaşmıştır.

Güçlü şekilde sanayileşmiş ülkelere bakıldığında; Arora ve Shi (2016), ABD için 1973-2014 döneminde (çeyrek dönemlere dayalı olarak) enerji tüketimi ve reel 
GSYIH arasındaki ilişkiyi Granger Nedensellik Analizi kullanarak araştıran çalışmalarında, özellikle ABD'de petrol tüketimi ve reel GSYiH arasında karşılıklı bir nedensellik ilişkisinin analiz edilen tüm zaman diliminde mevcut olduğu, 2009'dan sonra ise bu ilişkinin daha güçlü hale geldiği bulgusuna ulaşılmış; kömür tüketimi ile ekonomik büyüme arasındaki ilişkinin 1990'larda karşılıklı olduğu ancak 2000'lere gelindiğinde nedensellik ilişkisinin yalnızca reel GSYiH'den kömür tüketimine doğru olduğu; doğal gaz tüketimi ve reel GSYiH arasında 2000'lerin ortasına dek ekonomik büyümeden doğal gaz tüketimine doğru tek yönlü nedensellik ilişkisi olduğu ancak daha sonra ilişkinin bulunamadığı belirtilmiştir. Guo (2018)'nun, Çin 1978-1992 ve 1992-2016 dönemlerinde Granger Nedensellik Analizi'ni kullanarak yaptığı çalışmada enerji tüketiminden ekonomik büyümeye tek yönlü bir nedensellik bulunmuştur; bu sonuca göre Çin'de ekonomik büyüme enerji tüketimine güçlü şekilde bağlıdır. Eşbütünleşme ve hata düzeltme modellerinin sonucunda ise Çin'de \%1'lik enerji tüketimi artışının ekonomik büyümeyi \%1.2221 artırdığı bulunmuştur. Ghosh (2009), Hindistan'da ham petrol ithalat talebi ve ekonomik büyüme ilişkisini 1970-1971 ve 2005-2006 dönemi için ARDL modelini kullanarak incelediği çalışmada, uzun dönemde GSYiH ve ham petrol ithalatı arasında ilişki bulunmaktadır, GSYiH'deki \%1'lik artış, ham petrol ithalatı ihtiyacını \%1.97 artırmaktadır. Kısa dönemde ise değişkenler arası ilişki istatistiksel olarak anlamsızdır. Granger nedensellik analizi sonucunda ise ekonomik büyümeden ham petrol ithalatına tek yönlü nedensellik ilişkisi bulgusuna ulaşmışıtır: ekonomik büyüme, ham petrol ithalatının nedenidir.

Asghar (2008), beş Güney Afrika ülkesi için (Hindistan, Pakistan, Bangladeş, Nepal, Sri Lanka) farklı enerji türlerinin (petrol, gaz, kömür, elektrik, toplam enerji tüketimi) 1971-2003 (Sri Lanka için 1980-2003) dönemi enerji tüketimi ve ekonomik büyüme arasındaki ilişkiyi araştırdığı çalışmasında; toplam enerji tüketiminin Pakistan ve Nepal için büyümeden enerji tüketimine doğru olduğunu, yani ekonomik büyümenin enerji tüketimini artırdığını, ancak Bangladeş, Hindistan ve Nepal için büyüme ve toplam enerji tüketimi arasında ilişki bulgusuna rastlanmadığı; Bangladeş, Pakistan ve Sri Lanka'da ekonomik büyümenin elektrik tüketiminde artışa neden olduğu; Pakistan'da kömür, Nepal'de petrol, Bangladeş'te ise gaz tüketiminin ekonomik büyümenin nedeni olduğu bulgusuna 
ulaşılmıştır. Ekonomik büyümenin elektrik tüketiminde yarattığı artışın endüstriyel ve ticari aktivitelerdeki artış olması dayanak gösterilirken, buna bağılı olarak gaz tüketiminin ekonomik büyümeyi artırmasının da, bu aktiviteler için gerekli elektriğin sağlanmasında gaz kullanılması olduğu belirtilmektedir.

Jahangir ve Dural Yüce (2018), 1997-2015 döneminde Hazar Denizi bölgesinde ham petrol ve doğal gaz'ın ekonomik büyüme ile ilişkisini EKK ve Granger Nedensellik Analizi ile inceledikleri çalışmalarında, EKK sonuçlarına göre ham petrol ve doğal gaz değişkenlerinin ekonomik büyüme üzerinde önemli seviyede etkili olduğunu; özellikle ham petrol fiyatının ve doğal gaz üretimi değişkenlerinin tek başına da ekonomik büyüme üzerinde etkili olduğunu, diğer değişkenlerin (ham petrol ve doğal gaz için ayrı ayrı "üretim, rezerv, fiyat ve ihracat") ise ortak olarak büyümeyi etkilediğini; Granger Nedensellik Analizi'ne göre ise Hazar Denizi Bölgesi'nde GSYIH büyümesinin ham petrol fiyatının nedeni olduğunu belirtmektedir (çalışmada \%5 anlamlılık seviyesine bakılmaktadır, \%10 olsaydı ham petrol fiyatı da ekonomik büyümenin nedeni olarak bulunacaktır). Benzer şekilde GSYIH büyümesinin ham petrol ihracatının nedeni olduğu, ancak karşı yönde bir nedensellik ilişkisinin bulunmadığı; GSYiH büyümesinin doğal gaz fiyatı ve ihracatının nedeni olduğu belirtilmiş, rezervler ve üretimle GSYiH büyümesi arasında ise nedensellik ilişkisi bulunamamıştır.

\section{Veri, Yöntem ve Bulgular}

\subsection{Veri}

Çalışmanın uygulama bölümünde $A B$ ülkeleri ve $A B^{\prime} y e$ aday ülkelerin enerji ithalatının ekonomik büyümeleri üzerindeki etkisi panel veri yöntemiyle analiz edilmektedir. Panel veri analizi kullanmanın birçok avantajı vardır. Baltagi (2005)'ye göre panel veri kullanımı ile; bireylerin, firmaların, devlet veya ülkelerin heterojenliği ayrı olarak test edilebilir. Panel veri analizi; daha fazla bilgi veren veri kullanımı, daha fazla çeşitlilik, değişkenler arasında daha az doğrusallık, daha fazla serbestlik derecesi ve daha fazla etkinlik sağlar, ayrıca değişkenlerdeki değişim dinamiklerini çalışmak için daha faydalıdır. Yine panel veri, yalnızca yatay kesit veya yalnızca zaman serisi 
verilerinde gözlemlenmeyen etkileri tanımlamak ve ölçmek için daha avantajılır.

Çalışmada bağımlı değişken olan reel GSYï verileri The World Bank'ten; bağımsız değişkenler olan petrol ve petrol ürünleri ithalatı, doğal gaz ithalatı, katı yakıt ithalatı ve enerji ithalatı bağımlılık endeksi verileri ise Eurostat veritabanlarından elde edilmiştir. Reel GSYIH değişkeni ABD Doları; petrol ve petrol ürünleri ile katı fosil yakıt ithalatı "bin ton", doğal gaz ithalatı "milyon metreküp"; enerji ithatalatı bağımlılık endeksi ise yüzde cinsinden ifade edilmektedir. 2014-2018 dönemi beş yıllık veriler kullanılarak yapılan çalışmada veri eksikliği nedeniyle Kıbrıs, Malta ve Sırbistan analize dahil edilmemiştir, araştırılan ülke sayısı üçü aday ülke olmak üzere 28 'dir. Çalışmaya dahil edilen tüm ülkelerin verileri eksiksiz olup, veri seti dengeli panel veri şeklindedir.

\subsection{Temel Varsayımların Sınanması}

Modelin ilk aşamasında birim ve/veya zaman etkileri içerip içermediği analiz edilmiştir. En çok olabilirlik testi sonuçlarına göre modelde $\% 5$ anlamlılık düzeyinde birim veya zaman etkileri önce birlikte incelenmiştir. Sonuca göre birim ve/veya zaman etkisi bulunmadığı şeklindeki $\mathrm{H}_{0}$ hipotezi reddedilmektedir; iki etkiden birinin varlığı tespit edilmiştir. Ardından birim ve zaman etkileri ayrı ayrı incelenmiş ve $\% 5$ anlamlılık düzeyinde birim etkisinin bulunmadığı şeklindeki $\mathrm{H}_{0}$ hipotezi reddedilmiştir, birim etki bulunmaktadır; zaman etkisinin bulunmadığı şeklindeki $\mathrm{H}_{0}$ hipotezi ise reddedilememektedir, zaman etkisi yoktur sonucuna ulaşılmıştır.

Tablo 1: Birim ve Zaman Etkilerinin En Çok Olabilirlik Testi ile Sınanması

\begin{tabular}{|c|c|c|}
\hline Test Adı & Test İstatistiği & Olasılık Değeri \\
\hline Birim ve Zaman & 519.83 & 0.0000 \\
\hline Birim & 428.55 & 0.0000 \\
\hline Zaman & 0.00 & 1.0000 \\
\hline
\end{tabular}

Eğim parametresinin sabit, sabit parametrenin birimlere göre değişken olduğu "birim etkiler modeli", çalışmanın modelidir. 


$$
Y_{i t}=\beta_{0 i}=\sum_{k=1}^{K} \beta_{k} X_{k i t}+u_{i t} \quad \mathrm{i}=1, \ldots \ldots, \mathrm{N} ; \mathrm{t}
$$

Çalışmada birim etkilerin varlığı nedeniyle sabit veya tesadüfi etkiler modellerinden biri kullanılmalıdır. Bu iki model arasındaki seçim ise Hausman (1978) tarafından geliştirilen test kullanılarak bulunacaktır. Hausman Testi, parametreler arasındaki farkın sistematik olmadığı yönündeki $\mathrm{H}_{0}$ hipotezini test etmektedir. Hausman Testi için öncelikle sabit ve tesadüfi etkiler modelleri ayrı ayrı tahmin edilmiş, ardından test uygulanarak model seçimi yapılmıştır (Yerdelen Tatoğlu, 2016, s. 186-192).

Tablo 2: Hausman Testi

\begin{tabular}{|c|c|}
\hline Test İstatistiği & Olasılık Değeri \\
\hline 121.51 & 0.0000 \\
\hline
\end{tabular}

Hausman Testi sonucuna göre tesadüfi etkiler modelinin uygun olduğu yönündeki $\mathrm{H}_{0}$ hipotezi reddedilmektedir; sabit etkiler modeli kullanılmalıdır. Judge, Hill, Griffiths, Lutkepohl ve Lee (1985), N (yatay kesit birimler) büyük, t (zaman) küçükken sabit etkiler ve tesadüfi etkiler modellerinden elde edilen sonuçların önemli ölçüde farklılık gösterebildiğini, eğer örneklemdeki yatay kesit birimlerin büyük bir anakütleden tesadüfi olarak çekilmediğinden büyük oranda eminsek, sabit etkiler modelinin uygun olduğunu; eğer örneklemdeki birimler tesadüfi olarak çekildiyse, istatistiksel çıkarımın herhangi bir koşula bağı̆ı olmaması sebebiyle tesadüfi etkiler modelinin uygun olduğunu belirtmektedir (Gujarati ve Porter, 2009, s. 606). Bu çalışmadaki örneklem, aynı birlik içinde yer alan ve birbiriyle uyumlu özellikleri bulunan ülkelerden oluşması sebebiyle sabit etkiler modeline uygun görünmektedir. Hausman Testi sonucu da bu öngörüyü doğrulamaktadır.

Özellikle yatay kesit verileriyle çalışılırken karşılaşılan bir durum olan heteroskedasitenin varlığı, Greene (2000)'nin Değiştirilmiş Wald Testi ile sınanmaktadır. Değiştirilmiş Wald Testi, standart hataların normal dağıldığı varsayımı altında kullanılan LM, LR ve Wald Testlerinin aksine, normal dağılım varsayımı olmadığı durumda da kullanılabilmektedir (Yerdelen Tatoğlu, 2016, s. 220-222). 


$$
W=\sum_{i=1}^{n} \frac{\left(\hat{\sigma}_{i}^{2}-\sigma^{2}\right)}{V_{i}}
$$

Tablo 3: Heteroskedasitenin Değiştirilmiş Wald Testi ile Sınanması

\begin{tabular}{|cc|cc|}
\hline İstatistik Değeri & Olasılık Değeri \\
\hline 3830.63 & & 0.0000 \\
\hline & $\mathrm{H}_{0}: \sigma_{i}^{2}=\sigma^{2}$ & \\
& $\mathrm{H}_{1}: \sigma_{i}^{2} \neq \sigma^{2}$ & \\
\hline
\end{tabular}

Heteroskedasitenin olmadığı yönündeki $\mathrm{H}_{0}$ hipotezi \%5 anlamlılık düzeyinde reddilmektedir. Modelde heteroskedasite bulunmaktadır.

Modelde otokorelasyonun varlığı Bhargava, Franzini ve Narendranathan (1982)'ın Durbin-Watson Testi ve Baltagi-Wu (1999)' nun Yerel En İyi Değişmez (LBI) Testi ile sınanmaktadır. Test sonucunda yalnızca test istatistikleri bulunmaktadır; literatürde kritik değerler verilmemesine rağmen test istatistiklerinin 2'den küçük olması halinde otokorelasyonun varlığı kabul edilmektedir (Yerdelen Tatoğlu, 2016, s. 225-226). Çalışmada modele uygulanan test sonucunda istatistik değerleri 2'den küçük bulunmuştur; modelde otokorelasyon vardir.

Tablo 4: Otokorelasyonun Bhargava, Franzini ve Narendranathan'ın Durbin-Watson Testi ve Baltagi-Wu'nun Yerel En İyi Değişmez (LBI) Testi ile Sınanması

\begin{tabular}{|c|c|}
\hline Bhargava et al. Durbin-Watson & Baltagi-Wu LBI \\
\hline 0.72932056 & 1.4155263 \\
\hline
\end{tabular}

Modelde birimler arası korelasyonun varlığı Pesaran (2004)'ın testi ile sınanmaktadır. Pesaran Testi sonucuna göre $\mathrm{H}_{0}$ hipotezi $\% 5$ anlamlılık düzeyinde reddedilmektedir, modelde birimler arası korelasyon vardır. 
Tablo 5: Pesaran Testi

\begin{tabular}{|cc|}
\hline Test İstatistiği & Olasılık Değeri \\
\hline 21.524 & 0.0000 \\
\hline \multicolumn{2}{|c|}{$\mathrm{H}_{0}$ : Birimler arası korelasyon yoktur. } \\
& $\mathrm{H}_{1}$ : Birimler arası korelasyon vardır. \\
\hline
\end{tabular}

\subsection{Driscoll-Kraay Standart Hatalar Tahminci Modeli}

Sabit etkiler modeline uygulanan test sonuçlarına göre; modelde heteroskedasite, otokorelasyon ve birimler arası korelasyonun varlığı tespit edilmiştir. Varsayımlardan sapmaların bulunduğu bu durumda, dirençli tahminciler kullanılarak tahmin yapılması gereklidir. Çalışmada Driscoll ve Kraay (1998) tarafından geliştirilen Standart Hatalar Tahmincisi ile model tahmin edilecektir.

Tablo 6: Driscoll-Kraay Standart Hatalar Tahminci Modeli

\begin{tabular}{|l|c|c|c|c|c|c|}
\hline \multicolumn{2}{|c|}{ Katsayılar } & $\begin{array}{c}\text { Driscoll ve } \\
\text { Kraay } \\
\text { Standart } \\
\text { Hatalar }\end{array}$ & $\begin{array}{c}\text { t- } \\
\text { İstatistiği }\end{array}$ & $\begin{array}{l}\text { Olasılık } \\
\text { Değeri }\end{array}$ & \multicolumn{2}{|c|}{ Güven Aralığı (\%95) } \\
\hline Sabit Katsayı & 8.169282 & 0.6577815 & 12.42 & 0.000 & 6.342988 & 9.995576 \\
\hline $\begin{array}{l}\text { Ham Petrol } \\
\text { Ürünleri İthalatı }\end{array}$ & 0.4400398 & 0.0983948 & 4.47 & 0.011 & 0.1668521 & 0.7132275 \\
\hline $\begin{array}{l}\text { Doğal Gaz } \\
\text { Itthalatı }\end{array}$ & -0.00053 & 0.0200332 & -0.03 & 0.980 & -0.0561512 & 0.0550912 \\
\hline $\begin{array}{l}\text { Katı Fosil Yakıt } \\
\text { Ithalatı }\end{array}$ & -0.0356107 & 0.0187281 & -1.90 & 0.130 & -0.0876083 & 0.016387 \\
\hline $\begin{array}{l}\text { Enerji } \\
\text { Bağımlılığı }\end{array}$ & -0.020342 & 0.0071583 & -2.84 & 0.047 & -0.0402167 & 0.0004672 \\
\hline
\end{tabular}

\begin{tabular}{|c|c|c|c|}
\hline Gözlem Sayısı & F-Test İstatistiği & Olasılık Değeri & $\mathbf{R}^{\mathbf{2}}$ \\
\hline 140 & 3421.27 & 0.0000 & 0.3527 \\
\hline
\end{tabular}

\subsection{Bulgular}

Driscoll-Kraay Standart Hatalar Tahminci Modeli sonuçlarına göre, AB ülkelerinin enerji ithalatının GSYiH değeri üzerindeki etkisini test eden modelin $\mathrm{F}$ testi sonucu anlamlı bulunmuştur; model bir bütün olarak anlamlıdır. T testi sonuçlarına göre ise kullanılan bağımsız değişkenlerden petrol ve petrol ürünleri 
ithalatı ile enerji bağımlılığı değişkenleri anlamlı bulunmuştur. $A B$ ülkelerinin petrol ve petrol ürünleri ithalatında \% 1'lik artış, reel GSYIH'yi \%0.44 artırmaktadır. Petrol ve petrol ürünleri ithalatı ile reel GSYiH arasındaki bu pozitif yönlü ilişkinin varlığı, $A B$ ülkelerinin petrol ve petrol ürünleri ithalatının ekonomik büyümelerini artırdığı sonucunu vermektedir.

Diğer anlamlı bulunan bağımsız değişken olan $A B$ ülkelerinin enerji ithalatı bağımlılı̆ııın ise işareti negatiftir. Enerji ithalat bağımlılı̆̆ endeksindeki \%1'lik artış reel GSYIH'yi \%0.02 azaltmaktadır. Bu sonuç, AB'de enerji ithalatı bağımlılığındaki artışın ekonomik büyümeyi azaltacağını göstermektedir.

Diğer iki bağımsız değişken olan doğal gaz ithalatı ve katı yakıt ithalatının olasılık değerleri \%5 anlamlılık seviyesinde anlamlı bulunamamıştır. Belirginlik katsayısı olan $\mathrm{R}^{2}$ sonucuna göre, modeldeki bağımsız değişkenler, $A B$ ülkelerinin GSYïH'leri üzerindeki değişimlerin \%35'ini açıklamaktadır.

Eurostat (2021)'ın 2014-2018 dönemi Avrupa Birliği GSYïH'sinin sektörel dağılımı verilerine göre tüm yıllarda hizmetler sektörünün payı \%65 dolayındadır. International Energy Agency (2021)'nin aynı dönem verilerine göre ise petrol ve petrol ürünleri kullanımı ulaştırma sektörüne yoğunlaşmıştır. Petrol ürünlerinin ulaştırma sektöründe kullanımı diğer enerji ürünleri kullanımı toplamından daha yüksektir. Doğal gaz tüketimi en yoğun olarak konutlarda, kömür tüketimi ise sanayi sektöründedir. GSYiH içinde en yüksek payı hizmetler sektörünün oluşturması ve hizmetler sektöründe en yoğun kullanılan enerji ürününün petrol ürünleri olması, ampirik bulgulardaki petrol ve petrol ürünleri ithalatının GSYIH'yi olumlu etkilediği sonucunu desteklemektedir.

\section{Sonuç}

Enerji arzının coğrafi koşullar nedeniyle belli başı ülkelerin hakimiyetinde olması, bazı ülkeler için "enerji ithalatı bağımlılığı"nı beraberinde getirmektedir. Hanehalkı enerji gereksinimi dışında, özellikle sanayileşmiş ülkelerdeki enerji ihtiyacı, enerji bazlı fiyatlar genel düzeyinin etkilenmesi konusunda endişe 
oluşturmaktadır. Enerji bağımlılığının uzun yıllardır gündemde olduğu Avrupa Birliği ülkeleri, bu soruna çözüm için günümüzde yenilenebilir enerji kaynaklarına yönelmektedirler. Ancak hala yenilenemeyen enerji kaynaklarının kullanımı yoğun şekilde devam etmektedir. $A B$ ülkelerinin, yüksek enerji tüketimine karşın bu enerjiyi kendi kaynaklarından sağlayamamamaları, bu nedenle enerji ithalatına bağımlı ülkeler haline gelmeleri, ekonomik ve politik oriskleri beraberinde getirmektedir. Özellikle MENA ülkeleri ve Rusya'nın AB'nin enerji ithalatında çok büyük paya sahip olmaları, fakat ayn zamanda bu ülkelerin askeri ve siyasi olarak istikrarsız bölgeler olmaları, $A B$ ülkelerinin enerji güvenliğini tehdit etmektedir.

Bu çalışmada $A B$ ülkeleri ve $A B^{\prime} y e$ aday ülkelerin enerji ürünleri ithalatı ve enerji ürünleri ithalatına olan bağımlıllğının ekonomik büyümeleri ile ilişkisi panel veri analizi yöntemi ile araştııılmıştır. 2014-2018 dönemini kapsayan araştırmada, enerji ürünleri olarak petrol ve petrol ürünleri, doğal gaz ve katı yakıt ithalatının ekonomik büyüme ile ilişkisi araştırılmıştır. Çalışmada panel veri kullanılmış, temel varsayım testlerinin yapılması ile Driscoll-Kraay Standart Hatalar Tahmincisi'nin kullanımı uygun bulunmuştur. Tahmin sonucuna göre; petrol ve petrol ürünleri ithalatının ekonomik büyüme üzerindeki etkisi istatistiksel olarak anlamlı ve pozitifken, doğal gaz ve katı yakıtların ekonomik büyüme üzerindeki etkisi istatistiksel olarak anlamlı bulunamamıştır. Bu enerji ürünlerinden yalnızca petrol ürünlerinin ekonomik büyüme ile ilişkisinin anlamlı bulunması ve bu ilişkinin pozitif yönlü olması, AB ülkelerinin GSYIH'sinin büyük kısmının hizmetler sektörü tarafından sağlanması ve hizmetler sektöründe de petrol ürünlerinin yoğun olarak kullanıldığı ulaştırmanın yer alması ile açıklanabilir. Diğer bağımsız değişken olan enerji ithalatı bağımlılığının ise ekonomik büyüme üzerindeki etkisi beklendiği şekilde istatistiksel olarak anlamlı ve negatif yönlü olarak bulunmuştur. $A B$ ülkelerinin enerji ürünlerine olan bağımlılığı arttıkça ekonomik büyümeleri azalmaktadır.

Sonuçlar, enerji ürünleri ve ekonomik büyüme arasında pozitif yönlü ilişki olduğu yönündeki çalışmaları desteklemektedir. Enerji ürünlerini bu çalışmada olduğu gibi üç fosil yakıt üzerinden inceleyen ve gelişmişlik olarak $A B$ ile aynı kategoride bulunan $\mathrm{ABD}$ için bu enerji ürünleri kullanımının ekonomik büyüme ile 
ilişkisini araştıran Arora ve Shi (2016)'nin çalışmasına ait sonuçlar, her üç yakıt için de bu çalışma ile örtüşmektedir. Literatürde çoğunlukla enerji tüketimi değişkeni kullanılırken bu çalışmada $A B$ için "enerji ithalatı" değişkeninin kullanılması, ekonomik büyüme için enerji kullanımında dışa bağımlılığın daha iyi ölçülmesi açısından farklılaşmaktadır. Yapılan analiz, AB'nin enerji politikalarında önemli bir yere sahip olan enerji ithalatı bağımlılığının ekonomi için bir risk unsuru olduğunu doğrulamakta, yenilenebilir enerji gibi alternatif enerji ürünleri kullanımı ve enerji verimliliğinin artırılmasının yanı sıra, enerji ithal edilen kaynakların çeşitlendirilmesi gibi çözüm önerilerinin ekonomik büyüme üzerinde faydalı olabileceğine işaret etmektedir.

Hakem Değerlendirmesi: Dış bağımsız.

Çıkar Çatışması: Yazar çıkar çatışması bildirmemiştir.

Finansal Destek: Yazar bu çalışma için finansal destek almadığını beyan etmiştir.

Peer-review: Externally peer-reviewed.

Conflict of Interest: The author has no conflict of interest to declare.

Grant Support: The author declared that this study has received no financial support.

\section{Kaynaklar/References}

Arora , V. \& Shi, S. (2016). Energy consumption and economic growth in the United States, Applied Economics, 48(39), 3763-3773.

Asghar, Z. (2008). Energy-GDP Relationshıp: A Causal Analysis For The Five Countries Of South Asia, Applied Econometrics and International Development, 8(1), 167-180.

Aydın, F. (2010). Enerji Tüketimi ve Ekonomik Büyüme, Erciyes Üniversitesi İktisadi ve Idari Bilimler Fakültesi Dergisi, 0(35), 317-340.

Ayres, R. E., Turton, H. \& Casten, T. (2007). Energy efficiency, sustainability and economic growth, Energy, 32(5), 634-648.

Baltagi, B. H. (2005). Econometric Analysis of Panel Data (Third edition). West Sussex: John Wiley \& Sons Ltd.

Baltagi, B. H. \& Wu, P. X. (1999). Unequally Spaced Panel Data Regressions With Ar(1) Disturbances, Econometric Theory, 15(6), 814-882.

Barsky, R. B. \& Kilian, L. (2002). Do We Really Know that Oil Caused the Great Stagflation? A Monetary Alternative, In B. S. Bernanke \& K. Rogoff, NBER Macroeconomics Annual 2001 (pp.137-198), Cambridge, MA: MIT Press.

Bartoletto, S. (2012). Patterns of Energy Transitions The Long-Term Role of Energy in the Economic Growth of Europe, In N.Möllers \& K. Zachmann , Past and Present Energy Societies: How Energy Connects Politics, Technologies and Cultures, (pp. 305-330), Bielefeld: Transcript Verlag. 
Berndtson, E. (1991). Finlandization: Paradoxes of External and Internal Dynamics, Government and Opposition, 26(1), 21-33.

Beşer, N.Ö. \& Öztürk S. (2020). Petrol Fiyatlarinda Değişkenlik Ve İktisadi Büyüme: Petrol İthal Eden Ülkeler Üzerine Bir Analiz, Ekonomi Bilimleri Dergisi, 12(1), 68-84.

Bhargava, A., Franzni L. \& Narendranathan W. (1982). Serial Correlation and Fixed Effect Models, The Review of Economic Studies, 49(4), 533-549.

Bozkurt, C. \& Akan Y. (2014). Economic Growth, CO2 Emissions and Energy Consumption: The Turkish Case, International Journal of Energy Economics and Policy, 4(3), 484-494.

Campbell, C.J. (2005). Oil Crisis, Essex: Multi Science Publishing Company Ltd.

Canton, J., Tomasi M., Arnoldus P., Pienkowski J., Darnaut N., Maincent E., Rezessy A., Spooner M. \& Sripathy A. (2013). Member States' Energy Dependence: An Indicator-Based Assessment, European Economy Occasional Papers, 145.

Cherp, A., Adenikinju A., Goldthau A., Hernandez F., Hughes L., Jewell J., Olshanskaya M., Jansen J., Soares R. \& Vakulenko S. (2012). Energy and Security, In T. B. Johansson, N. Nakicenovic \& A. Patwardan, (Eds.), Global Energy Assessment: Toward a Sustainable Future, (pp. 325-383), Cambridge: Cambridge University Press.

Chevalier, JM. (2006). Security of energy supply for the European Union, European Review of Energy Markets, 1(3), 1-20.

Cirovic, M., Makajic-Nikolic D., Petrovic N., Vujosevic M. \& Kuzmanovic M. (2015). European Union Oil Import Dependency Risk Analysis, Polish Journal of Environmental Studies, 24(1), 75-81.

Driscoll, J.C. \& Kraay A. C. (1998). Consistent Covariance Matrix Estimation with Spatially Dependent Panel Data, Review of Economics and Statistics, 80(4), 549-560.

Esen, Ö. \& Bayrak M. (2017). Does more energy consumption support economic growth in net energyimporting countries?, Journal of Economics, Finance and Administrative Science, 22(42), 75-98.

Eurostat. (2021). Database. (2020, 25 Ocak). Erişim Adresi https://ec.europa.eu/eurostat

Georgantopoulos, A. G. \& Tsamis, A. D. (2011). The Relationship between Energy Consumption and GDP: A Causality Analysis on Balkan Countries, European Journal of Scientific Research, 61(3), 372-380.

Ghosh, S. (2009). Import demand of crude oil and economic growth: Evidence from India, Energy Policy, 37(2), 699-702.

Greene, W. (2000). Econometrics Analysis, New Jersey:Prentice-Hall.

Gujarati, D.N. \& Porter, D.C. (2009). Basic Econometrics (Fifth Edition), New York : McGraw Hill Inc.

Guo, W. (2018). An Analysis of energy consumption and economic growth of Cobb-Douglas production function based on ECM, IOP Conference Series: Earth and Environmental Science, 113.

Hamilton, J.D. (2003). What is an oil shock?, Journal of Econometrics, 113(2), 363-398.

Harbo, F. (2008). The European Gas and Oil Market: The Role of Norway, Note de l'Ifri.

Hausman, J.A. (1978). Specification Tests in Econometrics, Econometrica, 46(6), 1251-1271.

Hill, F. (2005). Beyond Co-Dependency: European Reliance on Russian Energy, The Brookings Institution US-Europe Analysis Series. (2020, 15 Ocak). Erişim Adresi https://www.brookings. edu/wp-content/uploads/2016/06/hill20050727.pdf 
International Energy Agency (2021). Data and Statistics. (2021, 25 Ocak). Erişim Adresi https://www. iea.org/data-and-statistics? country=WORLD\&fuel=Energy\%20 supply\&indicator= TPESbySource

Isaawi, C. (1978). The 1973 Oil Crisis and After, Journal of Post Keynesian Economics, 1(2), 3-26.

Jahangir, SMR. \& Dural Yüce, B. (2018). Crude oil, natural gas, and economic growth: impact and causality analysis in Caspian Sea region, International Journal of Management and Economics, 54 (3), 169-184.

Jochem, E. (2000). Energy End-Use Efficiency, In José Goldemberg et al. (Eds.), World Energy Assessment: Energy and the Challenge of Sustainability (pp.173-217), New York: UNDP.

Judge, G. G., Hill, R. C., Griffiths, W. E., Lutkepohl, H. \& Lee, T. C. (1985). Introduction to the Theory and Practice of Econometrics ( $2 d$ ed.), New York: John Wiley \& Sons.

Kasperowicz, R. \& Štreimikienè, D. (2016). Economic growth and energy consumption: comparative analysis of V4 and the "old" EU countries, Journal of International Studies, 9(2), 181-194.

Khatib, H. (2000). Energy Security, In José Goldemberg et al. (Eds.), World Energy Assessment: Energy and the Challenge of Sustainability (pp.111-131), New York: UNDP.

Korteweg, R. (2018). Energy as a tool of foreign policy of authoritarian states, in particular Russia, Belgium: European Parliament's Committee on Foreign Affairs. https://doi.org/10.2861/951739

Laqueur, W. (1977). Europe: The Specter of Finlandization, Commentary, 64 (6), 37-41.

Maltby, T. (2013). European Union energy policy integration: A case of European Commission policy entrepreneurship and increasing supranationalism, Energy Policy, 55, 435-444.

Marques, A. C., Fuinhas, J. A. \& Tomàs, C. (2019). Energy efficiency and sustainable growth in industrial sectors in European Union countries: A nonlinear ARDL approach, Journal of Cleaner Production, 239 (118045).

Martins, F., Felgueiras, C., Smitkova, M. \& Caetano, N. (2019). Analysis of Fossil Fuel Energy Consumption and Environmental Impacts in European Countries, Energies, 12(6), https://doi. org/10.3390/en12060964.

Matei, I. (2017). Is there a Link between Renewable Energy Consumption and Economic Growth? A Dynamic Panel Investigation for the OECD Countries, Revue d'économie politique, 127(6), 985-1012. Mucuk, M. \& Uysal, D. (2009). Türkiye Ekonomisinde Enerji Tüketimi ve Ekonomik Büyüme, Maliye Dergisi, 157, 105-115.

Örgün, B. O. \& Pala, A. (2017). Enerji Tüketimi, Dışa Açıklık ve Ekonomik Büyüme Ilişsisi: 28 Avrupa Birliği Ülkesi için Panel Granger Nedensellik Analizi, Finans Politik \& Ekonomik Yorumlar, 54(623), 9-20.

Özata, E. (2010). Türkiye'de Enerji Tüketimi ve Ekonomik Büyüme Arasındaki İlişkilerin Ekonometrik İncelemesi, Dumlupınar Üniversitesi Sosyal Bilimler Dergisi, 26.

Pesaran, M.H. (2004). General Diagnostic Tests for Cross Section Dependence in Panels, Cambridge Working Papers in Economics, 0435.

Pirlogea, C. \& Cicea, C. (2012). Econometric perspective of the energy consumption and economic growth relation in European Union, Renewable and Sustainable Energy Reviews, 16(8), 5718-5726. 
Streimikiene, D. \& Kasperowicz. (2016) R. Review of Economic Growth and Energy Consumption: A Panel Cointegration Analysis for EU Countries, Renewable and Sustainable Energy Reviews, 59, 1545-1549.

The World Bank.(2021). World Bank Open Data. (2021, 20 Ocak). Erişim Adresi https://data. worldbank.org/.

United Nations. (2021). UN Comtrade Database. (2021, 20 Ocak). Erişim Adresi https://comtrade. un.org/data.

Vlahinić-Dizdarević, N. \& Žiković, S. (2010). The role of energy in economic growth: the case of Croatia, Zbornik Radova Ekonomskog Fakulteta u Rijeci, 28(1), 35-60.

Yerdelen Tatoğlu, F. (2016). Panel Veri Ekonometrisi: Stata Uygulamalı, İstanbul: Beta Yayıncılık.

Yergin, D. (2006). Ensuring Energy Security, Foreign Affairs, 85(2), 69-82.

Yılmaz, S. \& Kalkan, D. K. (2017). Enerji Güvenliği Kavramı: 1973 Petrol Krizi Işığında Bir Tartışma", Uluslararası Kriz ve Siyaset Araştırmaları Dergisi, 1(3), 169-199. 